\title{
Representation, bargaining and the law: where next for the unions?*
}

\author{
Dr Michael DOHERTY
}

\section{Lecturer in Law, School of Law and Government/Socio-legal Research Centre, Dublin City University}

\begin{abstract}
Introduction
$\mathrm{T}$ The right to freedom of association and the right of trade unions to bargain on behalf of workers are rights that have long been internationally recognised. This can be seen in international law instruments such as the International Labour Organisation's (ILO) Convention No 87 of 1948, the Freedom of Association and Protection of the Right to Organise Convention and, under European law, in the shape of Article 28 of the European Union's Charter of Fundamental Rights and Article 11 of the European Convention on Human Rights and Fundamental Freedoms (ECHR). The right to freedom of association is also protected by Article 40.1.6(iii) of the Irish Constitution. However, as Hogan and Whyte point out, as interpreted by the Irish Supreme Court, this does not imply any duty on the employer beyond respecting the right in itself; in particular, "it does not oblige him to negotiate with any association which employees may form". 1

This constitutional position reflects the fact that trade union bargaining rights in Ireland, as in the UK, have traditionally been premised on the notion of "voluntarism", i.e. the avoidance of statutory regulation. ${ }^{2}$ The position in Ireland remains, however, unique in the Western world in that Irish trade unions have no legislative right to be recognised in the workplace for collective bargaining purposes. ${ }^{3}$ This article considers a recent attempt, in the form of the Industrial Relations (Amendment) Acts 2001-2004 (hereinafter referred to as "the Acts"), to address this situation. This research looked at the perceived effectiveness of the legislation from the point of view of the various employment relations stakeholders (unions, employees, employers and the state's industrial relations bodies), by way of a detailed examination of the day-to-day operation of the Acts by the Labour

* I would like to express profound thanks both to the anonymous reviewer and to Anthony Kerr of University College Dublin for the insightful and helpful comments received. I would also like to thank my colleagues in the Socio-Legal Research Centre at DCU, particularly Dr Noelle Higgins. Many thanks, too, to Sinead Ring (UCC) for her work in helping compile the data.

1 G Hogan and G Whyte, Kelly: The Irish Constitution 4th edn (Dublin: Butterworth 2003), p. 1803.

2 T Kerr and G Whyte, Irish Trade Union Law (Dublin: Butterworth 1985).

3 Twice, in 1967 and again in 1996, groups charged with reviewing the Constitution have considered whether a constitutional amendment was necessary in the area of freedom of association. In both cases, the view expressed was that this matter would be best dealt with by legislation; see Report of the Committee on the Constitution (1967) and Report of the Constitution Review Group (1996). A statutory procedure for gaining recognition rights now exists in the UK; see the Employment Relations Act 1999.
\end{abstract}


Court, from their coming into operation in June 2001 to the immediate aftermath of the decision of the Irish Supreme Court in the Ryanair case, ${ }^{4}$ which, as we will see, led many commentators to proclaim the legislation effectively neutered. ${ }^{5}$ The article questions whether the Acts can, despite the pessimism of many commentators, still play a role in Irish industrial relations (IR).

However, more broadly, the Acts represented an innovative attempt to steer a "half-way house" course between legally mandated collective bargaining and voluntarism. As a result, the article will also consider some possible implications of the "Irish model" for IR in other European jurisdictions, particularly in the light of recent developments concerning collective bargaining rights at EU level.

The article is laid out as follows. In the next section, the legislation and the decision in Ryanair will be outlined in more detail. Then, the methodology used in the analysis will be explained. The implications of the Ryanair decision will then be considered in light of the empirical evidence relating to the interpretation of the Acts. Finally, some implications of the Acts for industrial relations practice and collective bargaining more generally (in Ireland and elsewhere) will be teased out.

\section{The Industrial Relations Acts 2001-2004}

The absence of any statutory protection for collective bargaining became progressively more of a concern for the Irish trade union movement in the 1990s. This was partly because the decline in union density (the proportion of workers who are members of a trade union) became increasingly pronounced and partly as a result of a change in state policy in the 1980s, where state industrial development agencies began "marketing" Ireland (particularly to US multinational corporations (MNCs)) as a non-union environment. ${ }^{6}$ The unions' dissatisfaction was arguably compounded by the participation since 1987 of the Irish Congress of Trade Unions (ICTU) in the social partnership process, which has given the union movement a key institutional role at national level in relation to socio-economic policy, while at workplace level unions have no such institutional security and must fight recalcitrant employers for recognition rights.

As a result, the union movement pushed for progress on recognition rights for unions at workplace level. ${ }^{7}$ Under the fourth of the social partnership agreements, Partnership 2000, a high-level group comprising union and employer representatives and industrial relations experts was set up to examine the issue of trade union recognition rights. ${ }^{8}$ The result was the drawing up of the Code of Practice on Voluntary Dispute Resolution ${ }^{9}$ and the Industrial Relations (Amendment) Act 2001. The Code of Practice and the 2001 Act explicitly exclude the imposition of any "arrangements for collective bargaining", on the grounds of protecting Ireland's voluntarist tradition. The general philosophy behind both

4 Ryanair v The Labour Court [2007] 4 IR 199.

5 M Connolly, "Industrial Relations (Miscellaneous Provisions) Act 2004 - implications for industrial relations law and practice of the Supreme Court Decision in Ryanair v Labour Court and IMPACT" (2007) 4 IELJ 37; M Doherty, "Union sundown? The future of collective representation rights in Irish law" (2007) 4 IELJ 96; cf. A Kerr, "Industrial relations law" in M Regan (ed.), Employment Law (Dublin: Tottel 2008).

6 See J Wallace et al., Industrial Relations in Ireland (Dublin: Gill \& Macmillan 2004); T V Roche, "Pay determination, the state and the politics of industrial relations" in W K Murphy and T V Roche (eds), Irish Industrial Relations in Practice (Cork: Oak Tree Press 1997).

7 Particularly in the light of a bitter and high profile 1998 union recognition dispute at the airline company, Ryanair.

8 See para. 9.22 of Partnership 2000.

9 Industrial Relations Act 1990 (Code of Practice on Voluntary Dispute Resolution) (Declaration) Order 2000 (SI No 145 of 2000). 
is that disputes relating to union recognition should be dealt with within the context of voluntary collective bargaining (with parties offered recourse to the advisory and conciliation services of the Labour Relations Commission (LRC)). Thus, the 2001 Act does not provide for union recognition, but for a range of procedures to allow unions to seek to have specific disputes with regard to pay, terms and conditions of employment and dispute resolution procedures addressed. ${ }^{10}$ The provisions of the Act are used as a fallback measure whereby, in a situation where the parties cannot come to agreement under the "voluntary leg" of the process, a union or excepted body ${ }^{11}$ may request a further investigation by the Labour Court, which can issue a Recommendation. ${ }^{12}$ Should the issue remain unresolved, the court has the power to issue a legally binding Determination on pay and terms of employment. If the employer does not comply with a Labour Court Determination, the trade union may apply to the Circuit Court for an order directing the employer to carry out the Determination in accordance with its terms.

Changes to the legislation were agreed under the Sustaining Progress partnership agreement ${ }^{13}$ and resulted in the passing of the Industrial Relations (Miscellaneous Provisions) Act 2004. SI No 145 was repealed and replaced by the Industrial Relations Act 1990 (Enhanced Code of Practice on Voluntary Dispute Resolution) (Declaration) Order 2004. ${ }^{14}$ The 2004 Act provided that the processing of disputes under the Voluntary Dispute Resolution Code should take place within an indicative overall time frame of 26 weeks, with the possibility of extending it to a maximum of 34 weeks. Under the legislation, therefore, an employer may be compelled to grant union representatives the right to represent unionised employees on workplace issues relating to pay and terms and conditions of employment, but cannot be forced to make arrangements for collective bargaining.

\section{Fasten your seatbelts - the Ryanair case}

Trade unions had clearly hoped to use this legislation as a "springboard" to greater recognition rights, ${ }^{15}$ but such aspirations appear to have been dashed given the decision in Ryanair v The Labour Court. ${ }^{16}$ There, the Supreme Court upheld the company's complaints against the Labour Court's operation of the legislation, basing the decision on two key factors. First, the Supreme Court was highly critical of the procedures adopted by the Labour Court in hearing claims under the legislation. In particular, the Supreme Court felt that employees on behalf of whom claims were taken should ideally give oral evidence. The court held that the Labour Court did not adopt fair procedures by permitting complete non-disclosure of the identity of the persons on whose behalf the union was purporting to act. Furthermore, and most controversially, the Supreme Court criticised what it referred to as the Labour Court's "mindset", which favoured the way particular expressions are used

10 C Ryan, "Leaving it to the experts - in the matter of the Industrial Relations (Amendment) Act 2001" (2006) 3 IELJ 118.

11 "Excepted body" is defined by s. 6(3)(h) of the Trade Union Act 1941 (as inserted by s. 2 of the Trade Union Act 1942) and refers to "a body all the members of which are employed by the same employer and which carries on negotiations for the fixing of wages or other conditions of employment of its own members (but no other employees)".

12 Note the "Labour Court" is not part of the formal courts system but is a specially established industrial relations tribunal set up under the Industrial Relations Act 1946 to provide fair, informal and inexpensive arrangements for the adjudication and resolution of trade disputes.

13 See Art. 8.9 of Sustaining Progress.

14 SI No 176 of 2004.

15 B Sheehan, "Employers and the traditional industrial relations system: how the bonds have been loosened' in T Hastings (ed.), The State of the Unions (Dublin: Liffey Press 2008).

16 [2007] 4 IR 199. 
and particular activities are carried out by trade unions and which hinted that collective bargaining in a non-unionised company must take the same form and adopt the same procedures as would apply in collective bargaining with a trade union. This is somewhat surprising, as the Superior Courts have traditionally been quite deferential to the Labour Court's expertise in relation to industrial affairs. In the Ryanair case itself, Hanna $J$ in the High Court ${ }^{17}$ had endorsed this view:

The Labour Court is very much in charge of its own procedures. It has provided over many years a vital and invaluable service to the State in the often fraught area of industrial relations. It is not a court of law and the practice and procedure which it has evolved over the years, understandably, necessarily involved pursuing a less ritualistic and formalistic path than might be the case before these courts.

In fact, Hanna J pointed out, the present case was somewhat noteworthy in that lawyers did attend on behalf of the applicant. The Supreme Court's criticism of the procedures adopted by the Labour Court will likely have the effect of encouraging a greater formality in respect of Labour Court hearings and perhaps encourage a further "juridificiation" of the process. ${ }^{18}$

Secondly, the Supreme Court ruled that the Labour Court had erred in law (due partially to this "mindset") in its interpretation of the legislation; in particular, in deciding what was meant by the "practice" of "collective bargaining", in assessing when "internal procedures" had been exhausted, and in deciding what constituted an "excepted body". Essentially, the Supreme Court was not satisfied that the Labour Court was correctly confirming its jurisdiction to hear claims under s. 2 of the 2001 Act. As we will see, the number of claims processed under the 2001-2004 Acts has fallen dramatically in the wake of the decision.

\section{The sample and method}

This study looked at 103 Labour Court hearings up to, and including, the end of 2007, which were reported on the Labour Court website. ${ }^{19}$ Two hearings were reported in 2002; 10 in 2003; 20 in 2004; 31 in 2005; 31 in 2006; and 9 in 2007. It should be noted that 89 of these hearings ( 86 per cent of the total) were heard after the amendments introduced by the 2004 Act came into effect in April 2004. Eighty-nine different employers featured in the 103 hearings. ${ }^{20}$ If one looks at the occupational characteristics of the groups of employees involved in the cases, five sectors (using the Central Statistics Office (CSO) classification) ${ }^{21}$ accounted for the bulk of the cases; manufacturing industry; transport, storage and communication; wholesale and retail; real estate, renting and business activities (including security services); and community social and personal service activities (excluding health and education). When looked at in detail, the cases are almost exclusively taken in respect of relatively low-pay, low-skill groups of workers. ${ }^{22}$

Sixty-four of the employers involved in the hearings (72 per cent) were indigenous organisations, while 25 (28 per cent) were Irish subsidiaries of foreign-owned MNCs. It was not possible in all cases to establish the size of the workforces involved. However, of the 76 cases in which this information was ascertained, in 15 of the cases ( 20 per cent) the company employed fewer than 20 persons, in 35 cases (46 per cent) between 20 and 100

17 [2006] ELR 1, at p. 17. See also the judgment of Clarke J in Ashford Castle v SIPTU [2007] 4 IR 70.

18 J Browne, The Juridification of the Employment Relationship (Aldershot: Avebury 1994).

19 www.labourcourt.ie. Just two hearings were held in 2008. There were no hearings in 2009.

20 Some employers participated in multiple hearings (discussed further below).

21 See www.cso.ie/statistics/LabourForce.htm.

22 Although there are a limited number of exceptions; the airline pilots in the Ryanair case, for example. 
persons and in 26 cases (34 per cent) over 100 persons. Thus, the majority of cases involved relatively large employers, most of which were indigenous.

Of the 93 hearings where substantive issues were considered (i.e. excluding preliminary hearings under s. 2(1) of the 2001 Act discussed in the next section), binding Determinations under s. 6(1) were made in 26 cases (28 per cent). In 19 cases the Determination confirmed the original Recommendation in full and in seven cases it confirmed the Recommendation in part. ${ }^{23}$

A random sample of 48 hearings (47 per cent of the total) was chosen for more indepth analysis. $^{24}$ Remuneration $^{25}$ was at issue in 41 of the hearings. Grievance and disciplinary issues were at issue in 30 hearings. Of the latter, 21 specifically involved the situation where an employee or group of employees were seeking to be represented by a trade union representative in respect of grievance and/or disciplinary proceedings. Nonpay benefits (e.g. canteen facilities) were at issue in 11 cases, leave entitlements in 10, working hours and employer failure to comply with statutory obligations both featured in six cases with assorted "other" issues featuring in a further 17 cases. ${ }^{26}$ Thus, the issues raised involve traditional "core" union issues; pay and conditions and protection/representation in respect of grievances and disciplinary matters. Very few issues raised related to more "qualitative" issues (for example, family-friendly working).

\section{The Ryanair decision: procedures}

\section{CONFIRMING PRELIMINARY JURISDICTION}

Under s. 2(1)(a) of the Industrial Relations (Amendment) Act 2001 (as amended) the Labour Court may investigate a trade dispute where it is satisfied that:

it is not the practice of the employer to engage in collective bargaining negotiations in respect of the grade, group or category of workers who are party to the trade dispute and the internal dispute resolution procedures (if any) normally used by the parties concerned have failed to resolve the dispute.

Under s. 3 of the 2001 Act (as amended), any question as to whether the requirements specified in s. 2 have been met may, as the court considers appropriate, be determined either by way of a hearing preliminary to the court's investigation under that section, or as part of that investigation.

Of the 103 Labour Court hearings held prior to 2008, just 10 were preliminary hearings under s. 2, where the court did not discuss the substantive issues but considered only its jurisdiction to hear the union's claim. Of the 10, the court confirmed its jurisdiction in six cases and found it did not have jurisdiction to hear the case in the remaining four cases.

Of the 48 cases chosen for closer analysis, the employer made arguments contesting the Labour Court's jurisdiction to hear the claim in 20 cases. In four cases, the employer made submissions questioning the union's claim to represent employees; in six cases the company

23 S. 6 specifies that Determinations should be in the same terms as any Recommendation made under s. 5 , unless the court agrees a variation with the parties, or the court decides that the Recommendation, in whole or in part, was grounded on unsound or incomplete information.

24 Of these, in three cases there was no discussion of the substantive issues, as only the court's jurisdiction to hear the case was considered. As three of the hearings featuring Ashford Castle all involved the same issues, a sample of 43 cases involving distinct substantive issues was examined. The sample was random, except in the sense that, where a particular employer was involved in multiple hearings, all of these were examined.

25 Which here is taken to mean basic salary as well as issues like shift pay, overtime and sick pay.

26 For example, bullying and harassment, dignity at work; one case of victimisation on the grounds of trade union membership was raised. 
argued that internal procedures had not been exhausted; in three cases the employer argued that no trade dispute existed; in four cases the employer argued that it did, in fact, engage in collective bargaining with the relevant workers; in two cases the company argued that it engaged in collective bargaining with a different union to that taking the claim; and in one case the company claimed the union had engaged in industrial action (in breach of the Acts).

Overall, in the sample of 48 cases, the court confirmed its jurisdiction to hear claims in 42 (including three preliminary hearings). In the six cases where the court decided it did not have jurisdiction to hear the claim, it found in three cases that the employer did engage in collective bargaining, but with a union other than that taking the claim. ${ }^{27}$ In three further cases, the court found that internal procedures had not been exhausted. ${ }^{28}$

In Ryanair, the Supreme Court was critical of the Labour Court in respect of its failure adequately to address the issue of preliminary jurisdiction. The small number of standalone preliminary hearings held demonstrates that, in the vast majority of cases where jurisdiction was contested, the issue was decided by the Labour Court as part of the substantive investigation. In the light of Ryanair, it is likely more preliminary hearings will be necessary in future cases, as the preliminary examination would need to be more thorough and more formal procedures would need to be employed. This, of course, will have time and cost implications. Also, given the restrictive interpretations applied to key elements of s 2. of the 2001 Act in Ryanair (analysed below), it is likely more cases would emerge in which jurisdiction was not confirmed. This can already be seen in Bell Security. ${ }^{29}$

\section{IDENTITY OF UNION MEMBERS AND REPRESENTATION}

The Supreme Court in Ryanair held that the Labour Court did not adopt fair procedures by permitting complete non-disclosure of the identity of the persons on whose behalf the union was purporting to act. This aspect of the decision has led to a concern that, fearing victimisation from employers displaying a Ryanair-like aversion to trade unions, many employees would be likely to be discouraged from pursuing claims under the legislation. ${ }^{30}$ The issue had arisen before the Labour Court, which decided in Genesis Group $^{31}$ that the legislation:

does not require a trade union or excepted body to disclose the names or other identifying details of its members as a condition precedent to the making of an application.

The Supreme Court, however, seemed to view the issue of disclosure as a fundamental aspect of fair procedures. It is interesting that, in the immediate aftermath of the Ryanair decision, the LRC issued a press release, stating that, in its view, the verification of union

27 Fernley Airport Services (Case LCR18845 issued on 26/2/2007); Federal Security Services (Case LCR18621 issued on 4/07/2006); and MCM Security (Case LCR18206 issued on 26/05/2005).

28 See, for example, Banta Global Turnkey (Case DECP041 issued on 13/07/2004).

29 Case LCR19188 issued on 11/04/2008 discussed below at p. 395.

30 This point is particularly pertinent in the light of Geary's research, which showed that the propensity to unionise in non-union workplaces is especially manifest in situations where employers offer their support for union representation; the propensity to unionise drops markedly in situations where employers are not prepared to support union organisation. See J Geary, "Employee voice in the Irish workplace: status and prospect" in P Boxall et al. (eds), What Workers Say: Employee voice in the Anglo-American Workplace (Ithaca: Cornell UP 2007). It should be noted that there are anti-victimisation procedures under the Acts (ss. 8 and 9 of the $2004 \mathrm{Act}$ ), which have rarely been used.

31 Case DIR0511 issued on 22/9/2005. Note, however, that the Labour Court restricted the application of its decision to the members of the union. Therefore, although the union did not have to disclose its membership as a condition of making the application, it would have to disclose in order to benefit from the decision. 
members at the LRC stage of the process (at the request of employers) was in accordance with the Supreme Court's ruling:

this was done in a very straightforward way by the Advisory Officer obtaining a list of members from the trade union and cross checking this against the employer's own data such as payroll ... our advice is that, while we must satisfy ourselves that the trade union has members in the employment concerned, the judgement does not oblige us to compel a trade union to disclose to employers the names of those taken into membership. ${ }^{32}$

A related area of controversy is the extent to which unions taking claims under the legislation are, in fact, representative. In 78 of the 103 hearings (76 per cent) no information can be gleaned from the Labour Court report as to the number of members the union in question claimed to have in membership. In the other 24 cases, the number of members claimed varies significantly. In Castle T Furniture, ${ }^{33}$ for example, SIPTU (Services Industrial Professional and Technical Union) claimed to represent half of the 18 employees in the company, while in Schering Plough ${ }^{34}$ the union claimed to represent 306 of the 700 employees at the company plant. At the other end of the scale, in $Q K$ Cold Stores $^{35}$ the union's claim was on behalf of just seven employees out of a workforce of over 100, while, in Finlay Breton, ${ }^{36}$ BATU's (Building and Allied Trade Union) claim was in respect of three members out of a workforce of 300 . Thus, in some cases the unions involved pursued a claim where they declared to have a considerable existing presence, while in others claims were taken on behalf of a handful of employees only.

In three of the 48 cases chosen for closer analysis, the employer explicitly challenged before the Labour Court how representative the unions in question were. ${ }^{37}$ In Goode Concrete, 38 the company contended that the union was not actually representative of any of its employees and that there could not, therefore, be a dispute between it and the union. The union claimed to represent 30 drivers and offered to provide the court, on a confidential basis, with details concerning the number and identity of company employees who had joined the union, as the members did not consent to their identity being disclosed to their employer for reasons outlined to the court. The court noted that the Acts do not prescribe any membership threshold which a trade union must meet before it can bring an application under s. 2(1) and accepted the assurances of the union that it was representative of employees in dispute with the company.

The issue of verifying to what extent a union is representative of workers in dispute is now paramount in the light of Ryanair. Unions are, and have been, reluctant publicly to divulge information about membership levels in non-union companies for fear this may lead to employees being identified by employers and, potentially, being victimised or disadvantaged. The Supreme Court decision goes beyond this by explicitly requiring some identification of individual employees in dispute. This is so even though, as the Labour Court

32 www.lrc.ie $/$ viewdoc. asp?Docid $=555 \&$ Catid $=28 \&$ StartDate $=1+$ January $+2008 \& m=n$.

33 Case LCR19002 issued on 01/10/2007.

34 Case LCR18226 issued on 15/06/2005.

35 Case LCR18556 issued on 10/05/2006.

36 Case LCR 062 issued on 6/04/2006.

37 Hillview Nursing Home (Case LCR 18271 issued on 29/07/2005); Analog Devices (Case LCR18137 issued on 21/03/2005); and Goode Concrete (Case LCR18037 issued on 09/12/2004).

38 Goode Concrete (Case LCR18037 issued on 09/12/2004). 
has pointed out, there is no requirement under the legislation for unions to meet any representation threshold prior to taking a claim. ${ }^{39}$

This is a real problem for unions, not only as many (most?) members will likely be unwilling to put their heads above the parapet in pursuing a claim under the legislation, but also more broadly in the sense that evidence has shown that, in the absence of employer support, many Irish workers are fearful of the consequences of joining unions at all lest union membership damage their career prospects. ${ }^{40}$ In this sense, there may be some conflict between the position following the Supreme Court decision and Ireland's obligations under Article 11 of the ECHR. It should be remembered that in the Wilson and Palmer case ${ }^{41}$ the European Court of Human Rights found that "employees should be free to instruct or permit their union to make representations to their employer or to take action in support of their interests". ${ }^{42}$ The court went on to say that if workers were prevented from so doing, their freedom to belong to a trade union became illusory and that it was the "role of the State to ensure that trade union members were not prevented or restrained from using their union to represent them in attempts to regulate their relations with their employers". 43

In relation to the issue of identifiable union members giving evidence, one solution might be for some number of employees, on whose behalf the union is acting, to swear affidavits which would be supplied to the Labour Court. The court, having verified that the employees are union members and work for the company (in a manner similar to that outlined by the LRC above), could then supply anonymous versions of these to the employer. This, however, would run into another procedural issue identified by the Supreme Court that relates to oral evidence (discussed in the next section).

A second way out of the identification issue might be to re-fashion s. 2(1) altogether. Instead of fulfilling the criteria presently laid down in order to take a claim, a union could be required to meet some specified threshold of membership (which, again, could be verified by the LRC or Labour Court). This would have the advantage for employers of their not being subject to the legislation where only a handful of workers are union members. ${ }^{44}$ There is some recent precedence for this type of arrangement, too, in the Employee (Provision of Information and Consultation) Act 2006, which requires employers to inform and consult with employee representatives on a range of issues, where such a request is made by at least 10 per cent of the workforce. ${ }^{45}$ For the unions, where such a threshold was met, this approach would give "moral legitimacy" to their claims. This,

39 This idea of pressure on unions to disclose to courts and tribunals sensitive information regarding membership has interesting parallels with the view posited by some that the result of the ECJ's decisions in cases like Viking could well be that unions, in order to defend the proportionality of industrial action in claims relating to EU free movement rights, could be forced to disclose to national courts and tribunals potentially oppressive volumes of materials on internal union strategy, tactics and policy; see K Ewing and J Hendy, "The ECJ decisions and trade union freedom: lessons from the UK" in K Ewing and J Hendy (eds), The New Spectre Haunting Europe - The ECJ, trade union rights and the British government (Liverpool: Institute of Employment Rights 2009). Case C-438/05 International Transport Workers' Federation and Finnish Seamen's Union v Viking Line ABP [2008] IRLR 14. See further below, at 398.

40 Geary, "Employee voice", n. 30 above.

41 Wilson \& the NUJ, Palmer, \& Others v The UK [2002] IRLR 128.

42 Ibid., at para. 46 (emphasis added).

43 Ibid.

44 As in Finlay Breton, n. 36 above.

45 The 2006 Act implements Directive 2002/14/EC of 11 March 2002 establishing a general framework for informing and consulting employees in the European Community OJ L80/29; see M Doherty, "It's good to talk ... isn't it? Legislating for information and consultation in the Irish workplace” (2008) 15 DULJ 120. 
in fact, would not be a million miles from the position pre-2001, where unions took recognition claims under s. 20(1) of the Industrial Relations Act 1969. Recommendations under the 1969 Act that the employer should recognise the union in respect of those workers it had in membership were not binding on the employer and were often ignored. ${ }^{46}$ However, such a Recommendation still allowed a union taking industrial action in support of recognition to show that it had done its best to abide by procedures. Under the 2001-2004 Acts, of course, any Recommendation would not relate to union recognition, but would be binding.

Whether this would satisfy the unions is another question. As noted, the unions may have seen the legislation as a potential "springboard" to full recognition rights in companies. To meet a threshold unions would need to build up substantial support in a company prior to making a claim (a problem that has bedevilled British unions attempting to invoke the statutory recognition procedure there), ${ }^{47}$ whereas, under the present s. 2(1) they can invoke the legislation on behalf of any number of members, however small. Success can then result in a beneficial "demonstration" effect to other employees and help unions to garner more members. Similarly, from an employee's point of view, the purpose of the legislation, as outlined by Geoghegan $\mathrm{J}$ in Ryanair, was to protect employees in non-unionised companies from the obvious danger that: "employees may be exploited and may have to submit to what most reasonable people would consider to be grossly unfair terms and conditions of employment". ${ }^{48}$

One of the objectives of the Acts was to permit a right to representation for individual union members in the face of their employer's opposition. Because such employees, as individuals, normally have little bargaining power, the Acts accorded with arguably the main object of labour law; to be a countervailing force to counteract the inequality of bargaining inherent in the relationship, concealed by that "indispensable figment of the legal mind, the contract of employment". ${ }^{4}$

\section{ORAL EVIDENCE}

A final procedural issue raised by the Supreme Court related to oral evidence. The court felt that factual issues in dispute should be resolved on oral evidence from parties who participated in the process or who could give first-hand evidence on how the employer's procedures operated. ${ }^{50}$ Therefore, direct evidence on any issue is generally to be preferred to a legal submission, or an opinion or references to documents unsupported by direct evidence.

The reference here to an "opinion" is particularly worrying for the unions, as it relates to the issues discussed in the previous section around employees giving direct evidence. In order to protect employees' anonymity, the usual practice under the Acts has been for a union official to outline the employee case. Indeed, of the sample of 48 cases looked at here, in only one did an employee who was party to the dispute appear to give oral evidence. ${ }^{51}$ If direct evidence from those involved is to be preferred, this option will no longer be enough. It is interesting to note in Ryanair that Hanna J, in the High Court, ${ }^{52}$

46 C Higgins, "The right to bargain law: is it working?" (2001) 45 IRN.

47 See further below at n. 98.

48 [2007] 5 IR 99, at p. 215.

49 Kahn-Freund, Labour and the Law (London: Stevens \& Sons 1977), p. 6.

50 Therefore, the suggestion re "anonymous affidavits" mooted above would seem to fall foul of this aspect of the Supreme Court decision.

51 Little Rascal Crèche (Case LCR18648 issued on 24/07/2006).

52 [2006] ELR 1. 
pointed out that whether or not oral evidence is offered in a case is a call made on a daily basis by advocates before the ordinary courts, where parties are free to offer viva voce evidence or not as the case may be. He went on to observe that, while there might be circumstances in which the Labour Court might take a more "activist role" in determining what oral evidence it might wish to hear (for example, where there is a marked imbalance of "firepower" in the representation of the parties before it), this was not such a case.

\section{The Supreme Court decision: interpretation}

The second limb of the Supreme Court's criticism in Ryanair related to the interpretation given to key elements of the amended s. 2(1) of the 2001 Act by the Labour Court. For the Labour Court to assert jurisdiction in such cases it must be satisfied that it is not the "practice of the employer to engage in collective bargaining" with a trade union or an excepted body. The view accepted by the Labour Court was that if a group of employees unilaterally withdraws from the internal negotiating procedures, it could not thereafter be said that the employer had a practice of engaging in collective bargaining with them. The Labour Court laid down its definition of collective bargaining in the Ashford Castle $e^{53}$ case, noting that the expression is not defined in industrial relations legislation and that it is not a legal term of art:

Collective bargaining comprehends more than mere negotiation or consultation on individual employment related issues, including the processes of individual grievances in relation to pay or conditions of employment. In the industrial relations context in which the term is commonly used, it connotes a process by which employers or their representatives negotiate with representatives of a group or body of workers for the purpose of concluding a collective agreement fixing the pay and other conditions of employment applicable to the group of workers on whose behalf the negotiations are conducted.

Normally the process is characterised by the involvement of a trade union representing workers, but it may also be conducted by a staff association, which is an excepted body within the meaning of the Trade Union Act 1941, as amended. However an essential characteristic of collective bargaining, properly so called, is that it is conducted between parties of equal standing, who are independent in the sense that one is not controlled by the other.

The Supreme Court, however, objected to the view "arguably hinted at" in the definition that collective bargaining in a non-unionised company must take the same form and adopt the same procedures as would apply in collective bargaining with a trade union. The Supreme Court criticised the Labour Court for acknowledging a special, trade union meaning of the expression "collective bargaining negotiations" and held that the phrase should be given simply an ordinary meaning and not any distinctive meaning as understood in trade union negotiations. According to Geoghegan J:

if there is a machinery in Ryanair whereby the pilots may have their own independent representatives who sit around the table with representatives of Ryanair with a view to reaching agreement, if possible, that would seem to be "collective bargaining". 54

Furthermore, the unilateral withdrawal by employees from machinery put in place by the employer would not of itself entitle the employees to assert that there was no collective bargaining process in being; ultimately, where an employer has an internal non-union

53 Case DECP032 issued on 19/11/2003.

54 [2007] 4 IR 99, at p. 218. 
collective bargaining unit in place, this might constitute an excepted body under the legislation and satisfy the requirements of s. 2 .

The definition of collective bargaining provided by the Supreme Court and its indication that a collective bargaining unit can, it seems, amount to any group of employees as long as the group is recognised for this purpose by the company concerned have provoked much comment. In Ashford Castle v SIPTU, Clarke J, in the High Court, noted that the legislation:

only applies in circumstances where there is no collective bargaining. The only reasonable inference to draw from that provision is that the intention of the Oireachtas was to confer upon employees, who did not have the benefit of collective bargaining, a means of attempting to achieve terms and conditions comparable to those who had the benefit of collective bargaining. ${ }^{55}$

This was also the view underpinning the Labour Court's approach to the four cases examined in this research where the employer argued that it did, in fact, engage in collective bargaining. ${ }^{56}$

In Exel Technologies, ${ }^{57}$ the company claimed that "monthly communications meetings" were held to discuss all matters relating to employment, including pay and non-pay terms and conditions of employment, and were attended by elected staff representatives from each department. Therefore, the employer submitted, this process was no different from that which occurs in a company that engages with a trade union. SIPTU contended that the monthly communications meeting system was under the control of the employer and, consequently, employees had no appropriate means of processing claims with independent representation, no means of appeal, and no opportunity to refer to third parties. The court was satisfied that no details had been submitted by the employer to show that disputes concerning terms and conditions of employment were normally or routinely dealt with through this process. Consequently, the court found that the company's procedure was not of the type envisaged by s. 2(1)(a) of the Act.

In Ryanair, ${ }^{58}$ the company outlined a system (which it contended amounted to collective bargaining) whereby employees, including pilots, elect employee representatives to Employee Representative Committees (ERCs). The various ERCs then negotiate directly with the company on an ongoing basis in relation to all terms and conditions of employment. It was accepted that the Dublin pilot representatives had withdrawn from the ERC in August 2004 and no new representatives had been appointed. The court found that the ERCs were established by Ryanair and that the company had organised and controlled the election of employee representatives to them, including specifying the criteria of eligibility for election (e.g. no representative could serve more than one term). Employees were informed of the outcome of ERC discussions by Ryanair in a newsletter which it published and in respect of which it retained copyright. As a result (and by reference also to company documents) the Labour Court found that collective bargaining did not take place within the company.

The Labour Court will now have to rethink its underlying approach in the light of the Supreme Court decision. While the latter, significantly, did not set down precise rules or offer guidelines for the operation of a non-union internal bargaining unit, it seems from the

55 [2007] 4 IR 70, at p. 75.

56 In addition to the examples discussed in the text, see Little Rascal Crèche (Case LCR18648 issued on 24/07/2006) and Ashford Castle (Case DECP032 issued on 19/11/2003).

57 Case LCR18274 issued on 25/07/2005.

58 Case DECP051 issued on 25/01/2005. 
judgment that employers would be free to determine the form, structure and organisation of any internal collective bargaining units, as long as these have a degree of permanency and are not ad hoc. Thus, if an employer were to set up such a unit, it could presumably decide on issues such as how employees would be elected or chosen to be members, the remit of the unit, the terms of office of its members, and the rules and procedures of its operation. ${ }^{59}$

Disquiet has been expressed that the Supreme Court's definition of collective bargaining tends to ignore not only Ireland's industrial relations traditions, but also ILO Conventions and Declarations to which Ireland is a signatory. ${ }^{60}$ Ireland has ratified a number of ILO instruments, which explicitly require that the framework within which collective bargaining must take place if it is to be viable and effective be based on the principles of the independence and autonomy of the parties and the free and voluntary nature of the negotiations. ${ }^{61}$ Furthermore, ILO principles require that all legislation establishing machinery and procedures for arbitration and conciliation designed to facilitate bargaining between both sides of industry should guarantee the autonomy of parties to collective bargaining; explicitly excluded is the notion of employer-dominated bodies or company unions being considered as mechanisms for collective bargaining. ${ }^{62}$

Moreover, in addition to its international law obligations, there must be a real concern as to the compatibility of the Irish position with Article 28 of the Charter of Fundamental Rights, which guarantees the "right to negotiate and conclude collective agreements". With the entry into force of the Lisbon Treaty in December 2009, the Charter has attained the status of primary EU law. ${ }^{63}$ The provisions of the Charter, according to Title VII, are addressed to the institutions and bodies of the EU with due regard for the principle of subsidiarity and to the member states only when they are implementing EU law. However, there is an obligation on Community Institutions and Member States to promote the rights in the Charter. Finally, given that Ireland has now incorporated into domestic law the ECHR, 64 there is an obligation on the Irish Courts to interpret and apply any statutory provision on rule of law in a manner that is compatible with the country's obligations under the Convention. ${ }^{65}$ In this respect, it is important to note the recent decision of the European Court of Human Rights in Demir and Baykara v Turkey ${ }^{66}$ where the court declared that Article 11 of the ECHR includes a right to bargain collectively and precludes a blanket ban on a right to strike. ${ }^{67}$

There must be a real concern, therefore, that the Supreme Court, by not indicating more precisely what a non-union internal bargaining unit would look like, opens the possibility that employers will set up units that may not be genuine bargaining fora and thus

59 Doherty, "Union sundown", n. 5 above.

60 D D'Art and T Turner, "Ireland in breach of ILO conventions on freedom of association, claim academics" (2007) 11 IRN.

61 B Gernigon et al., "ILO principles concerning collective bargaining" (2000) 139 International Labour Review 33.

62 Ibid. at p. 44.

63 New Art. 6 Treaty on European Union.

64 By virtue of the European Convention on Human Rights Act 2003.

65 Ibid., s. 2.

66 Application No 34503/97, 12 November 2008. See also Enerji Yapi-Yol Sen v Turkey (Application No 68959/01, 21 April 2009).

67 Rulings which potentially bring the court's jurisprudence into conflict with that of the ECJ. 
abuse the process. At the very least, it seems, legislative intervention will be required. ${ }^{68}$ Most likely this will require a statutory definition of "collective bargaining". The ILO defines collective bargaining as:

all negotiations which take place between an employer, a group of employers or one or more employers' organisations, on the one hand, and one or more workers' organisations, on the other, for-

(a) determining working conditions and terms of employment; and/or

(b) regulating relations between employers and workers; and/or

(c) regulating relations between employers or their organisations and a workers' organisation or workers' organisations. ${ }^{69}$

Where national law or practice recognises the existence of other forms of workers' representatives, national law or practice can determine the extent to which the term collective bargaining shall also extend to negotiations with these representatives. ${ }^{70}$ Thus, although ILO definitions emphasise the role of trade unions in collective bargaining, they do recognise the potential role of non-union representatives. Crucially, however, they also insist that such representatives (and bargaining units) must be genuinely independent of employers. It can be argued that worker representatives (whether elected or appointed) who are employees of the undertaking, and therefore dependent on the goodwill of management for their employment and prospects of promotion, can never be genuinely independent. ${ }^{71}$ However, at a minimum, Irish legislation could be amended to, first, lay down conditions to be met regarding the establishment and operation of internal non-union bargaining units. ${ }^{72}$ Secondly, and in contrast to the Supreme Court's view, it might be provided that collective bargaining could not take place in a context where an employer refuses to engage with the trade union or excepted body which employees indicate (by way, perhaps, of ballot or independent verification) they wish to represent them.

The effects of the Supreme Court's decision can already be clearly seen. First, as noted above, the number of claims pursued under the Act has dropped dramatically and many union officials have proclaimed the Acts effectively dead. Secondly, the decision in Bell Security ${ }^{73}$ illustrates the new approach taken by the Labour Court. Here, two employees gave oral evidence to the court in support of the union's claim (both were union shop stewards). The Labour Court found that a trade dispute was in existence. It further found that the internal dispute resolution procedures had been exhausted. However, on the facts of the case the court decided that it was the company's practice to engage in collective bargaining with employees. The Labour Court's concluding remarks are worth quoting at this point:

68 One option would be to go down the UK route of statutory union recognition; this approach, though, would be strongly resisted by employer groups and does not seem to be favoured by the government; J Lavelle et al., "Unions on the edge? Industrial relations in multinational companies" in T Hastings (ed.), The State of the Unions (Dublin: Liffey Press 2008).

69 Art. 2 of ILO Convention (154) concerning the Promotion of Collective Bargaining (1981).

70 The ILO defines non-union worker representatives as "elected representatives, namely, representatives who are freely elected by the workers of the undertaking in accordance with provisions of national laws or regulations or of collective agreements and whose functions do not include activities which are recognised as the exclusive prerogative of trade unions in the country concerned"- Art. 3 of the Convention Concerning Protection and Facilities to be Afforded to Workers' Representatives in the Undertaking (1971).

71 D'Art and Turner, "Ireland in breach", n. 60.

72 A template of sorts can be found in Sched. 2 of the Employee (Provision of Information and Consultation) Act 2006, which lays down the standard rules for the establishment of an employee information and consultation forum.

73 Case LCR19188 issued on 11/04/2008. 
The Court accepts the union's submission that on the facts of this case there was an inherent and manifest inequality of negotiating capacity between the employee and management representatives. A professional HR specialist and senior managers represented the Company. Electricians who had no training or skills in negotiation or bargaining represented the employees. It is clear on the evidence that because of this the employee representatives came to see their role as involving little more than carrying messages back and forth and considered the process to be a waste of time and going nowhere.

It is nonetheless clear on the evidence that there was a practice whereby representatives of the employees, including representatives of the Dublin engineers, sat around a table with representatives of the Company with a view to reaching agreement if possible. That is collective bargaining negotiations for the purpose of the Act.

If the Court were considering the factual matrix of this case in an industrial relations context it might take a different view. However it must apply the law as it finds it and following the decision in Ryanair there can be no doubt as to the correct legal approach to the questions arising in this case.

Thus, the court accepted that the Supreme Court decision requires it to take an approach outside of the "industrial relations context". Of course, the court's unease with this, as well as its comments on the inequality of firepower between the parties, should be noted with concern. However, it does seem that it is the definition of "collective bargaining" that is key here. The union quoted both ILO and dictionary definitions. Legislative movement on this issue in line with these may well, therefore, have the effect of resuscitating the Acts.

\section{An "Irish model" for representation rights?}

The study did not seek to investigate in depth the extent to which union claims were successful or unsuccessful under the legislation. However, a number of points are noteworthy in terms of the Recommendations made by the Labour Court. This section will assess some of the key impacts of the legislation, focusing particularly on the extent to which the acts plugged the "representation gap" that exists where employers refuse to recognise employees' union(s). Moreover, potential implications of this "Irish model" for IR practice elsewhere are considered.

\section{Mandating THE "MOdel employeR" - AN IRISH approach to the "LAVAl Question"?}

In 34 of the 48 cases looked at in depth, the Labour Court made a Recommendation on remuneration. Two types of Recommendation are noteworthy. First, in eight of the cases, the court felt the company should pay the terms of the national pay agreement in place at the time. For example, in Creagh Transport, ${ }^{74}$ it was established that the company had no fixed or formal system of reviewing the pay of its employees. The company claimed that, due to the economic and commercial circumstances of the business, it had been unable to pay any increases for over four years. The Labour Court was of the view that the company's failure to provide for any increases in pay over such an extended period could not be justified. The court went on to say that, whilst the increases provided by national partnership agreements were not an automatic statutory or contractual entitlement, in the absence of any other established or agreed method of pay determination, they represented an "appropriate reference point" for establishing a fair and reasonable level of pay adjustment. The court rejected the submission that it was precluded from recommending increases in line with

74 Case LCR17933 issued on 18/08/2004. 
those provided by national agreements as any recommendation made by the court to that effect could be implemented without the necessity for collective bargaining at the level of the enterprise. The court recommended that, in future, pay should be adjusted by reference to the increases provided by national agreements subject to the right of the company to plead inability to pay through the mechanisms provided by those agreements.

Secondly, in 18 cases where a Recommendation on remuneration was made, this was on the basis of pay norms in the given industry. ${ }^{75}$ In Bank of Ireland, ${ }^{76}$ the court pointed out:

The powers which are given to the Court by the Act are a far reaching departure from the normal approach to the resolution of industrial relations disputes. They provided, in effect, that the Court may arbitrate in a dispute on the unilateral application of one party and in circumstances where the other party may not consent to the process. It seems to the Court that, having regard to the voluntary nature of our industrial relations system, such an intervention is only appropriate where it is necessary in order to provide protection to workers whose terms and conditions of employment, when viewed in their totality, are significantly out of line with appropriate standards.

Thus, the court, in its Recommendations on pay, has sought to introduce the idea of the "model employer"; in other words, it has effectively benchmarked respondent companies against others in the sector. This can be seen in Fournier Laboratories, ${ }^{77}$ where the Court found that the company's pay determination system was out of line with accepted standards in that it was based solely on performance assessment, rather than by reference to a basic "rate for the job", the predominant practice in the sector. Similarly, in Cooley Distillery, ${ }^{78}$ the court accepted pay rates agreed by the union (through collective bargaining) with other employers both locally and nationally as indicative of the industry norm. It recommended the respondent increase its pay rates to this more "appropriate standard" ${ }^{79}$

Therefore, where companies fall below the general, prevailing industry standards (as located by the court) they have been told to raise standards to that level (frequently identified as those set down by national pay agreements). From an employer's point of view, this can be seen as unwarranted interference with the right to operate a business and with property rights (as it effectively forces up industry norms in terms of pay). Furthermore, using the "unionised" standard of national agreements seems to threaten the right (recognised in Ryanair) to operate a non-union company. This most likely feeds into the Supreme Court's criticism of the Labour Court's "union mindset".

However, it has been frequently suggested (although evidence is somewhat sketchy) ${ }^{80}$ that in many industries the national agreements $d o$ act as a benchmark for non-union firms. In addition, in pay claims before the Labour Court under any legislation, the national agreements are arguably a useful benchmark to use. The alternative is for the court to

75 See, for example, Galway Clinic (Case LCR18815 issued on 18/01/2007).

76 Case LCR17745 issued on 28/01/2004.

77 Case LCR18582 issued on 24/05/2006. This decision of the Labour Court was quashed by way of a consent order, following the institution of Judicial Review proceedings, made by the High Court on 13 November 2007.

78 Case LCR17908 issued on 19/07/2004.

79 In Sterile Technologies (Case LCR17906 issued on 19/07/2004), the court, in holding pay rates were not out of line with industry norms, took account of the employer's provision of recently published survey information on comparable rates of pay compiled by the IBEC and the CSO. The court also noted that no industry comparators were put forward by the union.

80 Cf. D G Collings et al., "Between Boston and Berlin: American MNCs and the shifting contours of industrial relations in Ireland” (2008) 19(2) International Journal of HRM 242. 
depend on the parties' submissions on local and sectoral pay comparators. In such cases, both sides will have clear agendas, which can distort the true picture, information of this nature may be difficult to obtain and partial, and there are concerns about confidentiality. Furthermore, intervention in companies' wage-setting is nothing new; all employers are bound by the national minimum wage and some industries are subject to levels of pay set by Joint Industrial Councils (JICs) and Joint Labour Committees (JLCs). ${ }^{81}$ Clearly, though, there is a distinction between legally binding minimum standards and the setting of an industry wide "fair rate for the job" (particularly where the latter is set, not by the parties themselves in collective agreements, but by a state industrial relations tribunal).

It is this issue of binding minimum standards, as distinct from collectively agreed norms, that has been at the heart of controversial recent European Court of Justice (ECJ) decisions on collective rights. In a series of cases, Laval, Viking, Rüffert and Luxembourg, 82 the ECJ has severely affected the rights of trade unions and member states to protect collective agreements in cases where the rights of free movement of services or establishment are involved. The court ruled in Laval that, in accordance with the free movement of services provisions of the EC Treaty and the terms of the Posted Workers Directive (PWD), ${ }^{83}$ Swedish trade unions could not take industrial action to compel a Latvian builder operating in Stockholm, and "posting" Latvian workers there, to observe the terms and conditions of collective agreements operating in Sweden. Similarly, in Rüffert a Polish contractor could not be compelled to observe collective agreements that were locally, but not nationally, applicable and in Luxembourg posting employers could not be forced to observe collectively agreed minimum terms and conditions of employment beyond the mandatory matters listed in Article 3 of the PWD. At the heart of all these rulings is the view that where collective agreements are not declared universally applicable, extended erga omnes to nonunion workplaces, or their provisions protected, in some way, by member state legislation, they cannot be imposed on service providers from other EU jurisdictions operating in the member state in question. ${ }^{84}$ All that can be required of such service providers is that they observe statutory minima terms and conditions of employment.

In this respect, the Irish legislation, ironically, given that it falls short of union demands for strengthened collective bargaining rights, might offer a mechanism to protect "prevailing rates", rather than minimum standards, that would withstand ECJ scrutiny. In terms of fairness and social equity, the Labour Court approach, in attempting to benchmark and mandate good practice, has much to commend it. The court, after all, is explicitly set

81 See Parts IV and V of the Industrial Relations Act 1946. JLCs provide for the fixing of legally binding minimum rates of pay and the regulation of employment in certain sectors where there is little or no collective bargaining and where significant numbers of vulnerable workers are employed (e.g. the hotels sector). Collective agreements made by JICs (voluntary negotiating bodies for an industry or part of an industry, designed to facilitate collective bargaining at industry level in certain sectors) are also registered with the Labour Court and are legally binding. They generally exist in sectors with a relatively high level of unionisation (e.g. the construction sector). The Industrial Relations Amendment Bill 2009 (just published at the time of writing) seeks to strengthen both mechanisms.

82 Case C-341/05 Laval v Svenska Byggnadsarbetareförbundet [2007] ECR I-11767; Case C-438/05 International Transport Workers' Federation and Finnish Seamen's Union v Viking Line ABP [2008] IRLR 14; Case C-346/06 Rüffert $\mathrm{v}$ Land Niedersachsen [2008] IRLR 467; and Case C-319/06 European Commission v Luxembourg [2009] IRLR 388.

83 Directive 96/71/EC of 16 December 1996 concerning the posting of workers in the framework of the provision of services OJ L18/01.

84 See S Deakin, "The labour law perspective: the economic implications of the decisions" (2007-08) 10 CYELS 463; C Barnard, "Viking and Laval: a single market perspective" in K Ewing and J Hendy (eds), The New Spectre Haunting Europe - The ECJ, trade union rights and the British government (Liverpool: Institute of Employment Rights 2009); A C L Davies, “One step forward, two steps back? The Viking and Laval Cases in the ECJ” (2008) 37(2) Industrial Law Journal 126. 
up to reflect and accommodate the different, often conflicting, interests of labour and business in the interest of employment relations harmony. However, it has been persuasively argued 85 that the Irish judiciary in a number of major areas of constitutional interpretation frequently tends to defer to individual values, and particularly individual property rights, over those of the community or collective groups. This approach of the Superior Courts is, perhaps, visible again in the Ryanair decision. It would require a legislative (or Supreme Court) rethinking of what "bargaining" entails in the Irish context (in line with ILO and ECHR formulations) for the Acts to truly offer a way out of the Laval dilemma. We will return to this question in the concluding section.

\section{A Trojan horse? Union recognition under the Acts}

A key concern of employers has been that the Acts effectively promote a form of "back door" union recognition; that essentially the Acts allow unions to get their "foot in the door" and force employers to deal with them on some level. ${ }^{86}$ Undoubtedly, the unions hoped that this would be the case. It should be noted, however, that in only two cases, Federal Security Services Ltd ${ }^{87}$ and Hillview Nursing Home $e^{88}$ did employers actually concede bargaining recognition to a union (and in both cases, the employer decided to recognise unions other than those taking the respective claims). Therefore, neither the fears of employers nor the hopes of the unions seem to be borne out empirically.

Nevertheless, the Acts have had some interesting effects worthy of comment. In a limited number of rulings, the Labour Court seemed to indicate that, on certain issues, unions and their members should have a collective influence. This can be seen in Carlingford Nursing Home ${ }^{89}$ where it was recommended that the company put in place a new harassment and equal treatment policy. In drawing this up, the union (SIPTU) was to be permitted to make submissions on the content of such policies and these submissions were to be taken into account. More starkly, perhaps, in the long-running saga involving Ashford Castle ${ }^{90}$ the company (while not conceding union recognition) eventually indicated to the Court that it would be prepared to facilitate the union in providing paid training for its shop stewards, who could then represent members in grievance procedures.

Most worryingly of all for non-union employers is the case of Esker Lodge nursing home, where it was reported that the Irish Business and Employers' Confederation (IBEC) may have advised the company to recognise the union on pragmatic grounds; that is, that it would be easier to simply concede recognition than to become caught up in the procedure under the Acts. ${ }^{91}$ It should be stressed, though, that there seems little further evidence of cases where unions have been able to use the spectre of the Acts to persuade employers to engage directly in a traditional collective bargaining relationship.

In this respect, the Acts throw up an intriguing dilemma for unions. Taking claims under the Acts involves considerable time and expense. Often claims are taken on behalf of non-members, and frequently in respect of small groups of workers. Although unions may have been willing to pursue these claims initially in an attempt to demonstrate the

85 G Morgan, A Judgment Too Far? Judicial activism and the Constitution (Cork: Cork UP 2001); in relation to trade union rights, see p. $38 \mathrm{ff}$.

86 See, for example, T Dobbins, "Union recognition law used for benchmarking private sector pay" (2005) 36 IRN.

87 See n. 27 above.

88 Case LCR18440 issued on 22/12/2005.

89 Case LCR17932 issued on 17/08/2004.

90 Case LCR18820 issued on 22/01/2007.

91 T Dobbins, “Fear' of 2004 Act persuades nursing home to concede full recognition” (2006) 36 IRN. 
value of union representation to non-union workforces, the sustainability of such a strategy is questionable. It certainly is not a traditional form of union representation nor does it fit within many of the prescriptions offered to halt union decline in the literature on union "revitalisation". 92

Furthermore, the fact that the legislation explicitly excludes Recommendations on collective bargaining and empowers the court to deal only with specific, defined issues, means that unions may face the prospect of being forced to take multiple claims against a particular employer. The study showed that 89 different employers featured in the 103 hearings, but some employers featured in multiple hearings; Ashford Castle, for example, was involved in four separate hearings. ${ }^{93}$ Again, this type of action probably involves an unsustainable commitment of union time and resources. Clearly, the unions will take such cases in order to try and persuade employers to recognise them in a traditional bargaining relationship. Where employers refuse, however, multiple claims seem to be the only option under the legislation. Outside of the impacts on unions and employers (who will have the threat of Labour Court imposed pay and conditions hanging over them), there are important public policy considerations here also, not least the implications in terms of the growing demands on the time and resources of the LRC and the Labour Court.

A final issue needs to be addressed here in relation to union recognition. As noted above, one of the key objections to any attempts to introduce a statutory recognition procedure (along the lines of the UK) has been the alleged threat this would pose to foreign direct investment (primarily from US MNCs) on which the Irish economy is so dependent. Similar concerns have been voiced about the impact of the 2001-2004 Acts on MNC activity in Ireland. ${ }^{94}$ In this regard, it should be noted that the study reveals the majority of cases involved indigenous employers (72 per cent). Although the number of cases involving MNCs is perhaps higher than had been previously thought, ${ }^{95}$ the main impact of the legislation, as we have seen, has been on employers whose pay and conditions fall below the industry norm. The larger, "flagship" MNCs, where HR practices would generally be relatively sophisticated and where pay and conditions of employment would generally be at the higher end of the spectrum, barely feature at all. ${ }^{96}$ Thus, the focus on the "threat to investment" argument seems to be misplaced.

\section{Conclusion}

This article considered the operation of the 2001-2004 right to bargain legislation in the light of the seminal Supreme Court decision in the Ryanair case. Throughout, the concern was to identify, first, whether the legislation has any future role to play and, secondly, to consider the impacts of the Acts and the Ryanair decision on the various IR stakeholders for whom the rights (or lack thereof) to union representation is of paramount concern. On the first issue, various suggestions were made that could have the effect of "resuscitating" the legislation, in particular a re-formulation of the definition of "collective bargaining".97

92 C Frege and J Kelly, Union Revitalisation Strategies in Comparative Perspective (Sage: London 2003).

93 Case DECP032 issued on 19/11/2003; Case LCR17760 issued on 23/03/2004; Case LCR17914 issued on 22/07/2004; and Case LCR188220 issued on 22/01/2007; as well as a High Court hearing: [2007] 4 IR 70.

94 See n. 6 above.

95 Sheehan, "Employers", n. 15 above.

96 And, for example, in GE Healthcare (Case LCR18013 issued on 22/11/2004) SIPTU's pay claim was rejected by the court as employees had actually received pay increases in excess of the national pay deals.

97 See also E Gilvarry and B Hunt, "Trade union recognition and the Labour Court: picking up the pieces after Ryanair" in T Hastings (ed.), The State of the Unions (Dublin: Liffey Press 2008). 
On the second issue, there must be a real concern that Irish law remains unique in the Western world in not offering legally guaranteed rights to union representation.

However, the innovative nature of the legislation is worthy of some concluding comments in the light of recent developments in other EU jurisdictions. First, it has been noted that the UK, with a similar voluntarist tradition to Ireland (albeit without the corporatist tendencies evident in the social partnership era), introduced a mandatory union recognition law under the 1999 Employment Relations Act. The legislation has certainly not been an unqualified success from the point of view of bolstering collective bargaining there, as, while there has been a sharp decline in the derecognition of unions, concerns have been expressed that recognition has been primarily achieved in "core" union constituencies (where existing membership levels are relatively high); that the scope of collective bargaining is relatively restricted and more often represents consultative, rather than joint, regulation; and that the delays and costs of organising recognition ballots frustrate efforts to recruit and retain members. ${ }^{98}$ Recognition laws, clearly, are not a panacea for union ills. ${ }^{99}$

Secondly, we have discussed above the impact of recent ECJ decisions regarding the interaction between economic rights and the right to uphold collective agreements. The ECJ has effectively made voluntary collective agreements that require service providers to comply with terms and conditions that go beyond statutory minima impossible to enforce against providers from other EU jurisdictions. The Irish legislation and the Labour Court's operation thereof, at least before its emasculation in the Ryanair case, did provide an opportunity for prevailing norms in an industry or (through voluntary national pay deals) the economy as a whole to be enforced, even where these exceeded statutory minimum standards. Where legal protection for collective bargaining rights under EU law appears to be under threat, it may be that the Irish approach offers an alternative model worthy of exploration.

98 See, for example, R Dukes, “The statutory recognition procedure 1999: no bias in favour of recognition?" (2008) 37(2) Industrial Law Journal 236; W Brown and D Nash, "What has been happening to collective bargaining under New Labour? Interpreting WERS 2004” (2008) 39(2) Industrial Relations Journal 91; B McArthur, "The efficacy of statutory union recognition under New Labour: a comparative review" (2004) 20(3) International Journal of Comparative Labour Law and Industrial Relations 399; and S Oxenbridge et al., "Initial responses to the statutory recognition provisions of the Employment Relations Act 1999" (2003) 41(2) British Journal of Industrial Relations 315.

99 As Kahn-Freund put it "a healthy union movement can take a great deal of legal intervention whilst weak unions may be its victim"; Labour and the Law, n. 49 above, at p. 121. 
